U.S. Department of the Interior

U.S. Geological Survey

\section{Water-Quality Summary of the San Marcos \\ Springs Riverine System, San Marcos, \\ Texas, July-August 1994}

San Marcos Springs is the second largest spring in Texas and is the headwaters for the San Marcos River in San Marcos. Spring Lake (fig. 1) was built in 1848 at the site of a marsh formed by the springs to provide hydropower to a mill. The San Marcos River originates from the 15-acre lake and flows approximately 4 river miles (mi) south to its confluence with the Blanco River. The mean annual flow of the San Marcos River is about 170 cubic feet per second $\left(\mathrm{ft}^{3} / \mathrm{s}\right)$.

The water from San Marcos Springs is some of the most pristine in Texas. In addition to being a valued economic and recreational resource to the region, San Marcos Springs and the associated riverine system provide habitat to several unique native aquatic species identified for protection under the Endangered Species Act. Species designated as endangered are the fountain darter (Etheostoma fonticola), the San Marcos gambusia (Gambusia georgei), the Texas blind salamander (Typhlomolge rathbuni), and the Texas wild rice (Zizania texana). The San Marcos salamander (Eurycea nana) is designated as threatened. Spring Lake and upper parts of the San Marcos River have been designated as critical habitat for these species, (except for the Texas blind salamander) (U.S. Fish and Wildlife Service, 1995).

To better understand the environmental needs of these species, the U.S. Fish and Wildlife Service (USFWS) undertook an intensive ecological assessment of the San Marcos Springs riverine system. A primary objective of the study was to obtain information about the water chemistry of the endangered species habitat. To that end, the U.S. Geological Survey (USGS) provided continuous monitoring of selected water-quality properties and discrete water-quality sampling at selected sites along the San Marcos Springs riverine system during July and August 1994. The purpose of this fact sheet is to summarize the methods and results of the USGS water-quality monitoring and sampling.

\section{Data Collection}

Water-quality data were collected at four sites along the San Marcos River (fig. 1). The most upstream site (site 1) is on the
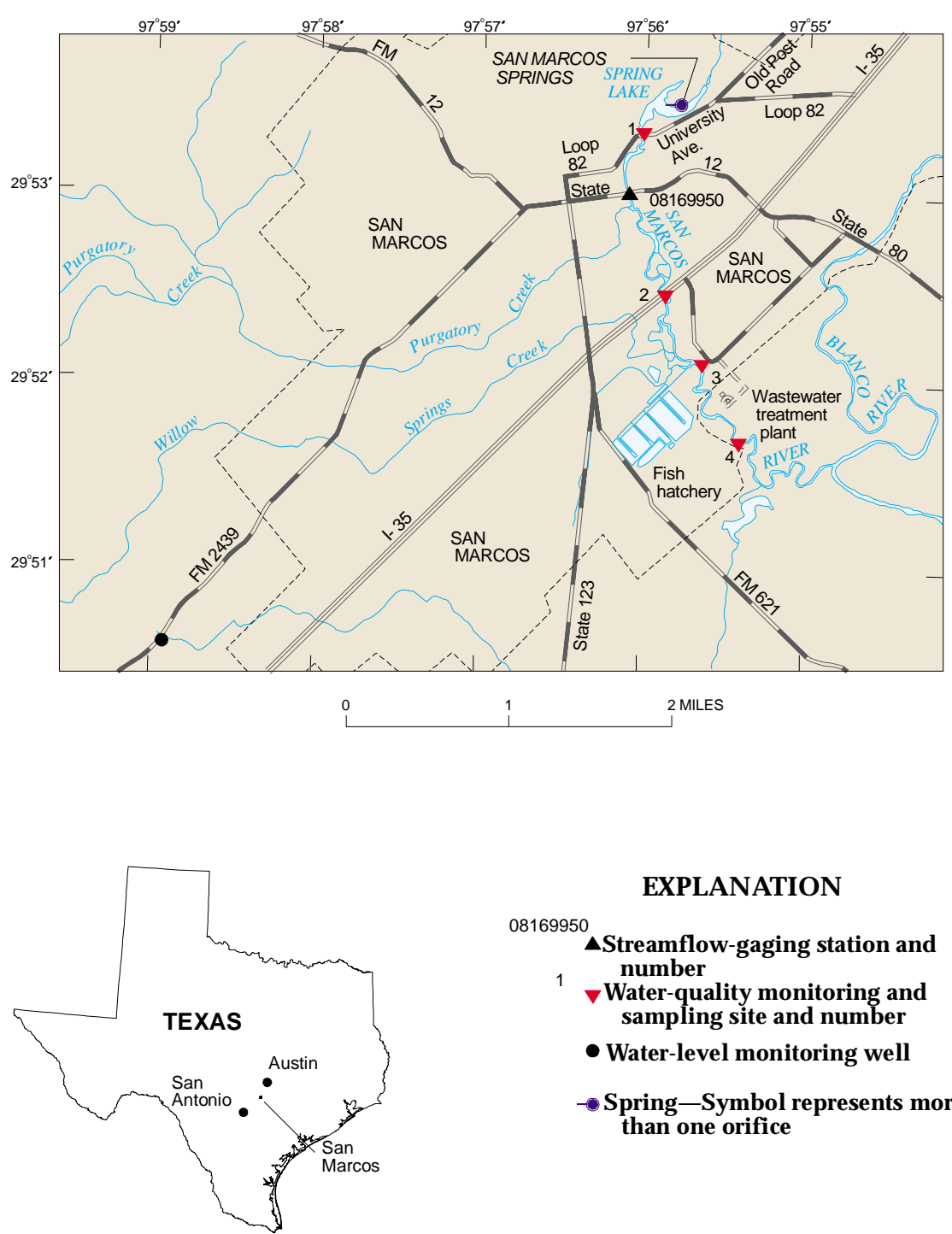

EXPLANATION

08169950

$\Delta$ Streamflow-gaging station and number

$\nabla$ Water-quality monitoring and sampling site and number

- Water-level monitoring well

- Spring-Symbol represents more than one orifice

Figure 1. Locations of monitoring and sampling sites.

San Marcos River at University Avenue in San Marcos. Data collected from this site characterize water emanating from the springs and represent a composite of the water from Spring Lake. Site 2 is on the San Marcos River at the downstream side of I-35. Water-quality changes within the river system between sites 1 and 2 would be reflected in samples from site 2 . Site 3 is on the San Marcos River downstream of a fish hatchery; it was selected to monitor the possible effects on water quality of upstream urban runoff and discharge from the fish hatchery. Site 4 is on the San Marcos River downstream of a municipal wastewater treatment plant. Data collected from this site reflect the cumulative changes in the stream water quality along the entire reach. 
Data collection during the study comprised (1) continuous monitoring at all sites for specific conductance, $\mathrm{pH}$, temperature, and dissolved oxygen; (2) one discrete water-quality sample at each site that was analyzed for selected properties, major ions, nutrients, trace elements, and selected organic compounds; and (3) continuous measurement of flow from San Marcos Springs.

For continuous water-property monitoring, each site was equipped with a four-parameter monitoring instrument with a solar-powered data logger (onsite data-storage device). Because of limited access to the sites, self-contained, floating shelters were used to house and support the monitoring equipment. Before equipment installation at each site, measurements were made of the selected parameters to be monitored at crosssectional points to confirm that a single monitoring point would be representative of the site. To ensure quality data, monitoring instruments were calibrated before installation. Sites were visited periodically for instrument maintenance, recalibration, and verification of accuracy.

Specific conductance, $\mathrm{pH}$, temperature, and dissolved oxygen were monitored and logged at 30-minute intervals during July 1August 30, 1994. The data set was edited to exclude periods of storm runoff and instrument probe malfunctions; and also to contain only concurrent data for all sites for the monitoring period of July 9-August 29, 1994. Periods of unused record are July 21-August 10, and August 21-23, 1994. The edited data set contained 1,331 data values per constituent per site.

Water-quality samples were collected from sites 1 and 2 on August 17, 1994, and from sites 3 and 4 on August 18, 1994. The samples at each site, except those for analysis of selected organic compounds, were collected using a depth-integrated method at multiple intervals along the cross section and then composited. Samples for selected organic compounds were collected using a depth-integrated method at the midpoint in the stream. Continuous springflow was computed from a regression between continuous water-level measurements in a nearby well (fig. 1) and periodic streamflow measurements at a streamflowgaging station on the San Marcos River (station 08169950) (fig. 1).

\section{Observations}

During the monitoring period, San Marcos Springs flow decreased steadily from a daily mean of $135 \mathrm{ft}^{3} / \mathrm{s}$ on July 1 , 1994, to $124 \mathrm{ft}^{3} / \mathrm{s}$ on August 31, 1994 (fig. 2). Boxplots show the distributions of specific conductance, $\mathrm{pH}$, temperature, and dissolved oxygen by sampling site (fig. 3). Except for site 3, median specific conductance increases slightly with distance downstream of San Marcos Springs. Median specific conductance is 582,585 , and 590 microsiemens per centimeter $(\mu \mathrm{S} / \mathrm{cm})$ at sites 1,2, and 4, respectively. Site 3 has a median of 577 $\mu \mathrm{S} / \mathrm{cm}$. Median $\mathrm{pH}$ also increases downstream, ranging from 7.4 at site 1 to 7.8 at site 4 . Minimum range in $\mathrm{pH}$ is 0.2 at site 1 and maximum range is 0.5 at site 2 . Median temperature also increases downstream, ranging from 22.6 degrees Celsius $\left({ }^{\circ} \mathrm{C}\right)$ at site 1 to $24.3^{\circ} \mathrm{C}$ at site 4 . Minimum range in temperature is 2.0 ${ }^{\circ} \mathrm{C}$ at site 1 and maximum range is $3.3^{\circ} \mathrm{C}$ at sites 2 and 3 . Median dissolved oxygen varies with distance downstream, ranging from 7.8 to 8.3 . The range in dissolved oxygen at a site is from 2.5 to $4.8 \mathrm{mg} / \mathrm{L}$.

Concentrations for selected properties, major ions, nutrients, and trace elements are listed in table 1. Among the major ions analyzed for, only slight differences in concentrations are observed between sites. The sum of dissolved constituents ranges from $310 \mathrm{mg} / \mathrm{L}$ at site 3 to $344 \mathrm{mg} / \mathrm{L}$ at site 4 .

Nutrient concentrations are similar at sites 1, 2, and 3, but slightly higher at site 4 . At sites 1, 2, and 3, ammonia nitrogen concentrations are between 0.030 and $0.040 \mathrm{mg} / \mathrm{L}$; total nitrogen

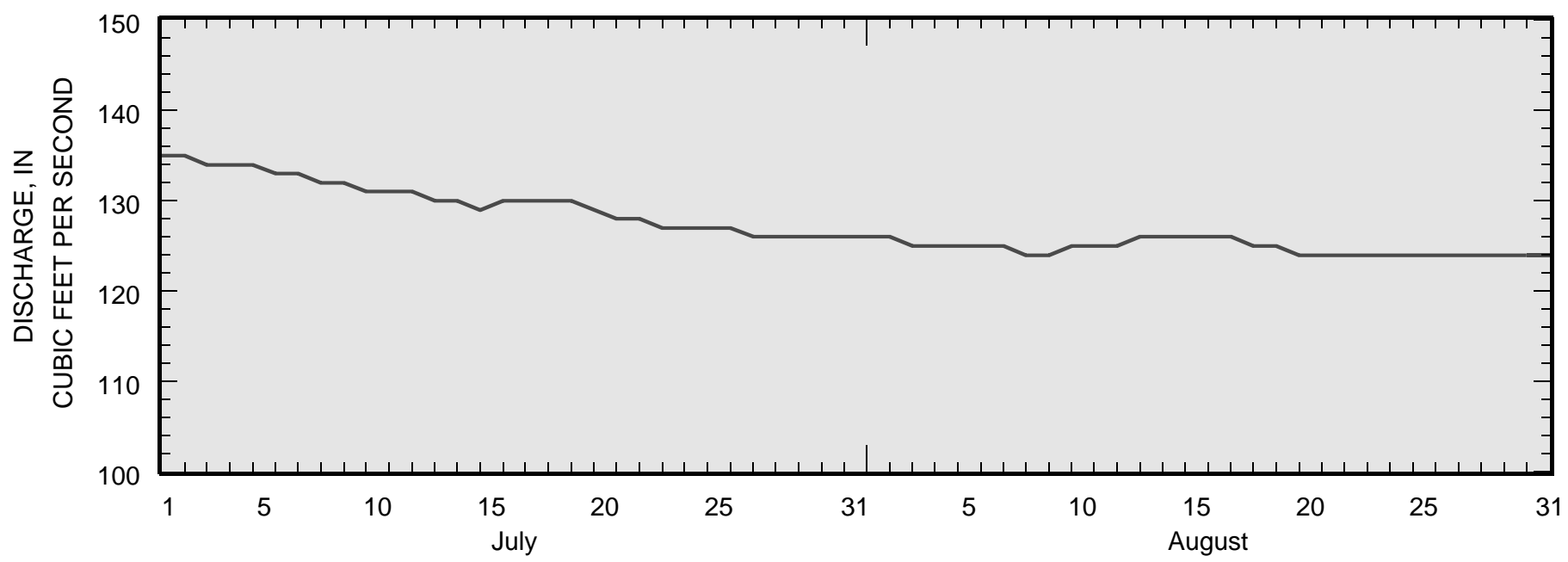

1994

Figure 2. Hydrograph showing daily mean discharge for San Marcos Springs, San Marcos, Texas, July 1-August 31, 1994. 

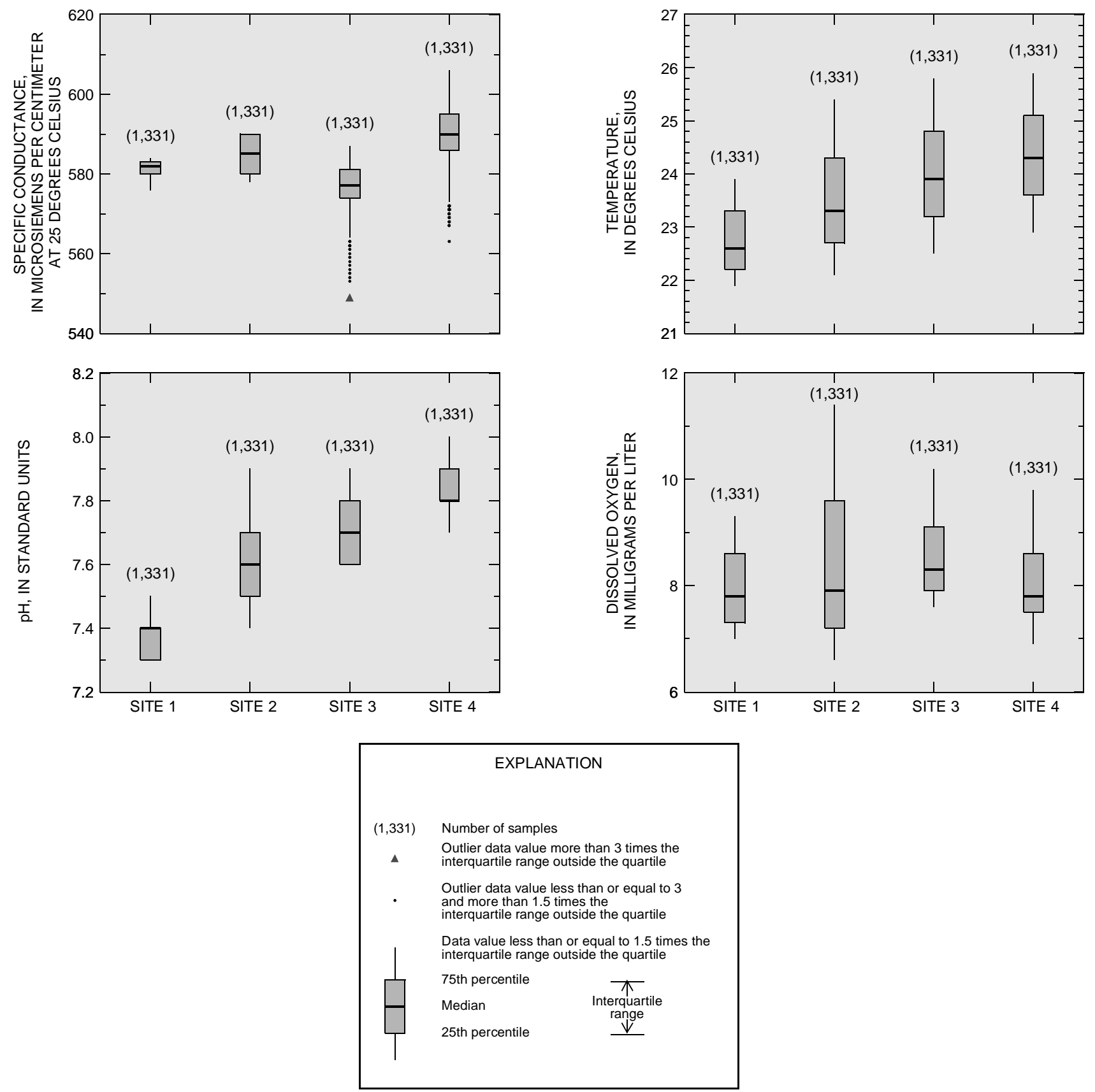

Figure 3. Distributions of specific conductance, $\mathrm{pH}$, temperature, and dissolved oxygen, San Marcos Springs, San Marcos, Texas, July-August 1994.

concentrations are 1.10 to $1.20 \mathrm{mg} / \mathrm{L}$; and dissolved phosphorus concentrations are $<0.01$ to $0.030 \mathrm{mg} / \mathrm{L}$. At site 4 , ammonia nitrogen concentrations are $0.080 \mathrm{mg} / \mathrm{L}$; total nitrogen concentrations are $1.80 \mathrm{mg} / \mathrm{L}$; and dissolved phosphorus concentrations are $0.130 \mathrm{mg} / \mathrm{L}$.

Trace-element concentrations in samples from all sites are at or below detection limits for all of the constituents except barium, iron, lead, manganese, and strontium. Detectable iron concentrations are in samples from 1 of the 4 sites; detectable lead concentrations are in samples from 2 of the 4 sites; and detect- able concentrations of barium, manganese, and strontium are in samples from all sites.

None of the four sites had detectable concentrations of the selected organic compounds (table 2).

\section{Reference}

U.S. Fish and Wildlife Service, 1995, San Marcos/Comal Springs (revised) recovery plan: Albuquerque, N. Mex., $93 \mathrm{p}$. 
Table 1. Concentrations of selected constituents, San Marcos Springs, San Marcos, Texas, July-August 1994

$\left[\mu \mathrm{S} / \mathrm{cm}\right.$, microsiemens per centimeter at 25 degrees Celsius; ${ }^{\circ} \mathrm{C}$, degrees Celsius; $\mathrm{mg} / \mathrm{L}$, milligrams per liter; --, no data; <, less than detection limit; $\mu \mathrm{g} / \mathrm{L}$, micrograms per liter]

\begin{tabular}{lccccc}
\hline \multicolumn{1}{c}{$\begin{array}{c}\text { Selected properties } \\
\text { and major ions }\end{array}$} & Site 1 & Site 2 & Site 3 & Site 4 \\
\hline Specific conductance $(\mu \mathrm{S} / \mathrm{cm})$ & 588 & 589 & 582 & 608 \\
$\mathrm{pH}($ standard units) & 7.8 & 7.5 & 7.6 & 7.7 \\
Temperature $\left({ }^{\circ} \mathrm{C}\right)$ & 23.0 & 22.5 & 23.0 & 23.5 \\
Dissolved oxygen $(\mathrm{mg} / \mathrm{L})$ & 8.8 & 8.0 & 8.6 & 8.3 \\
Calcium, dissolved (mg/L) & 86 & 86 & 82 & 86 \\
Magnesium, dissolved (mg/L) & 17 & 17 & 16 & 17 \\
Sodium, dissolved (mg/L) & 11 & 11 & 11 & 16 \\
\hline Potassium, dissolved (mg/L) & 1.4 & 3.3 & 1.3 & 1.9 \\
Sulfate, dissolved (mg/L) & 23 & 24 & 23 & 26 \\
Chloride, dissolved (mg/L) & 19 & 18 & 19 & 24 \\
Fluoride, dissolved (mg/L) & .20 & .20 & .20 & .20 \\
Silica, dissolved (mg/L) & 11 & 11 & 11 & 11 \\
Dissolved solids, sum of & 328 & 331 & 310 & 344 \\
$\quad$ constituents (mg/L) & & & &
\end{tabular}

Nutrients (mg/L)

\begin{tabular}{|c|c|c|c|c|}
\hline Nitrogen, nitrate, dissolved & -- & -- & -- & 1.76 \\
\hline Nitrogen, nitrite, dissolved & $<.01$ & $<.01$ & $<.01$ & .040 \\
\hline Nitrogen, ammonia, dissolved & .030 & .030 & .040 & .080 \\
\hline Nitrogen, total & 1.20 & 1.20 & 1.10 & 1.80 \\
\hline Phosphorus, dissolved & $<.01$ & $<.01$ & .030 & .130 \\
\hline Phosphate, ortho, dissolved & .03 & -- & .03 & .34 \\
\hline
\end{tabular}

Trace elements $(\mu \mathrm{g} / \mathrm{L})$

\begin{tabular}{lcccc} 
Arsenic, dissolved & $<1$ & $<1$ & 1 & $<1$ \\
Barium, dissolved & 36 & 37 & 35 & 35 \\
Cadmium, dissolved & 1.0 & $<1.0$ & $<1.0$ & $<1.0$ \\
Chromium, dissolved & $<5$ & $<5$ & $<5$ & $<5$ \\
Copper, dissolved & $<10$ & $<10$ & $<10$ & $<10$ \\
Iron, dissolved & $<3$ & $<3$ & $<3$ & 4 \\
Lead, dissolved & $<10$ & 20 & $<10$ & 20 \\
Manganese, dissolved & 1 & 3 & 5 & 4 \\
Mercury, dissolved & $<.1$ & $<.1$ & $<.1$ & $<.1$ \\
Nickel, dissolved & $<10$ & $<10$ & $<10$ & $<10$ \\
Selenium, dissolved & $<1$ & $<1$ & $<1$ & $<1$ \\
Silver, dissolved & $<1.0$ & $<1.0$ & $<1.0$ & $<1.0$ \\
Strontium, dissolved & 540 & 540 & 520 & 540 \\
Zinc, dissolved & $<3$ & $<3$ & $<3$ & $<3$ \\
\hline
\end{tabular}

—R.N. Slattery and Lynne Fahlquist

Any use of trade, product, or firm names is for descriptive purposes only and does not imply endorsement by the U.S. Government.
Table 2. Selected organic compounds for which analyses obtained and detection limits, San Marcos Springs, San Marcos, Texas, July-August 1994

$[\mu \mathrm{g} / \mathrm{L}$, micrograms per liter; $<$, less than detection limit]

\begin{tabular}{lc}
\hline Selected organic compounds & $\begin{array}{c}\text { Detection limit } \\
(\mu \mathbf{g} / \mathbf{L})\end{array}$ \\
\hline PCB & $<0.1$ \\
Polychlorinated naphthalene & $<.10$ \\
\hline Aldrin & $<.010$ \\
\hline Chlordane & $<.1$ \\
Diazinon & $<.010$ \\
\hline Dieldrin & $<.010$ \\
Endosulfan & $<.010$ \\
\hline Ethion & $<.010$ \\
\hline Heptachlor & $<.010$ \\
\hline Lindane & $<.010$ \\
\hline Malathion & $<.010$ \\
\hline Methoxychlor & $<.01$ \\
\hline Methylparathion & $<.01$ \\
\hline Mirex & $<.01$ \\
\hline Parathion & $<.01$ \\
\hline Perthane & $<.1$ \\
\hline Silvex & $<.01$ \\
\hline Toxaphene & $<1$ \\
Trithion & $<.01$ \\
2,4-D & $<.01$ \\
2,4-DP & $<.01$ \\
\hline 2,4,5-T & $<.01$ \\
\hline & \\
\hline & \\
\hline &
\end{tabular}

\section{U.S. DEPARTMENT OF THE INTERIOR U.S. GEOLOGICAL SURVEY}

Information on technical reports and hydrologic data related to this and other studies can be obtained from:

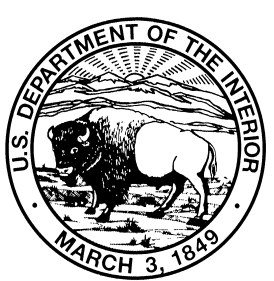

Subdistrict Chief

U.S. Geological Survey

435 Isom Road, Suite 234

San Antonio, TX 78216

Phone: (210) 321-5200

FAX: (210) 530-6008

Email: gbozuna@usgs.gov

World Wide Web: http://txwww.cr.usgs.gov 